\title{
The Policy of Exile and Exclusion in the Mamluk State
}

\author{
Ghassan Weshah* \\ Head of History and Archeology Department at the Islamic University of Gaza
}

*Corresponding Author: Ghassan Weshah, Head of History and Archeology Department at the Islamic University of Gaza.

\begin{abstract}
The Mamluk state in Egypt and the Levant (1250-1517) was one of the most important Islamic countries that played an important role in the formation of Islamic history. It overcame the two greatest threats to the Islamic state in the middle Ages, the Crusader threat and the Mongol threat. The internal front has been played by the internal front of the Mamluk of the red lines. For this reason, the state has followed the policy of exile and exile. Many of the princes and senior men of the state have been subjected to exile and deportation. A new term in this country is the term "unemployed" He has a very expensive job That there were some of the attention of the Mamluk State in directing cases of exile and deportation, such as Jerusalem, Damietta and Damascus, and there seem to be reasons that made Jerusalem the first objective of the denial of some of the characters ... Jerusalem was the preferred place for those who are subject to the penalty of exile was some of the exiles enter the mediation at The Sultan to convert the place of exile to Jerusalem and because of the sanctity of this city, and its status in the Islamic law, the exile gets the wages of Rabat and worship, as well as its moderate climate.
\end{abstract}

\section{INTRODUCTION}

The Mamluk were a dynasty of soldiers that ruled Egypt, the Levant, Iraq and the Arabian Peninsula more than two and a half centuries, specifically from 1250 to 1517 . The Mamluk were slaves of Turkish origin from Central Asia. They established in Egypt and the Levant two consecutive states whose capital was Cairo at the time:

The first is the Mamluk maritime state, one of the most prominent sultans is Ezzedine Aybak, Qataz, Zaher Baybars, Mansour Qalawun, Nasser Muhammad Ibn Qalawun and Ashraf Salah Eddin Khalil.

Second: the state of the Mamluk tower that came in a military coup by the Circassian Sultan Barqouq, who later confronted Timorlank and regained what was occupied by the Tatars in the Levant and Iraq, including Baghdad. The state of the Mamluks of the tower, which was known in the era began the maximum expansion of the Mamluk state in the ninth century AH. Among their most prominent sultans was Barqouq, his son Faraj, Anal, Ashraf Saif al-Din Barsbay, the light of Cyprus, Qansoh alGhouri, and Tuman Bay.

We will discuss the policy of the Mamluk state on the issue of exile and exile to many princes, sultans and army leaders, as well as talk about the lives of the two halves in all respects, and we will learn about the real reasons and motives behind the policy of exile.

\section{RESEARCH IMPORTANCE}

- Writing in a new topic, not addressed by one of the researchers

- To stand on the truth of things and to explain the reasons and the correct motives behind the policy of exile and exclusion in the Mamluk state.

- Explain the desire of the exiles to direct their exile to the city of Jerusalem instead of any other city.

- To highlight the role of exiles in public life in the cities to which they were exiled.

\section{STUDY APPROACH}

The researcher used the historical approach in the study. 
Divisions of the study: The study was divided into an introduction and four topics and a conclusion:

\subsection{The First Topic / Reasons and Motives Behind the Policy of Exile and Exclusion}

\subsubsection{First: Definition}

Exile:

Language: exile is the distance from the country and means forcibly expelled from the country and ${ }^{1}$ expelled ${ }^{(1)}$

Unemployed:

The term "unemployed" is the unemployed of soldiers and princes for the actions of the state and its functions as a result of the anger of the Sultan or old age or the need to retreat and disappear for the sole love of getting away

The researcher sees, after clarifying these two concepts, finds that not every unemployed person is exiled outside the borders of the state. However, every exiled person is unemployed, so we will see later that many of the princes are unemployed, they are banished and this reinforces the correction of the base ${ }^{(2)}$

\subsubsection{Second: The Reasons and Motives for Exile and Exclusion}

a) The prince or the leader asks the exile himself (a personal request)

In the year (783 AH - 1381 AD), Prince Teshmetr Allay asked to transfer him and exile him from Safed's office to Jerusalem in order to live there unemployed ${ }^{(3)}$

In the year 707 AH -1307 AD, Prince Karay was from Upper Egypt. He claimed sickness at his home and did not go out to the castle. Then he asked to be exempt from the emirate and to live in Jerusalem as an unemployed, and he apologized because of his many diseases. He went to Cairo and rewarded Prince Saif al-Din Al-Mansouri ${ }^{2}$

Year (783 AH -1381 AD) Prince Tgrash (prince of the weapon) gave up his job and went to the Qusun Mosque to establish an unemployed ${ }^{(5)}$

In the year (784 AH - $1382 \mathrm{AD}$ ) in Ramadan, Teshtamer al-Dweidar was replaced by the prosecution of Safad Fa'afi and turned to Jerusalem unemployed ${ }^{(6)}$

\section{b) The arrogance in talking with the Sultan and not taking into account the politeness}

In 820 AH-1417M, Sultan Al-Muayad Abu Al-Nasr, Saif al-Din Sheikh Al-Mahmoudi Al-Dhaheri, presented to the deputy of Al-Sham. He informed him that Qajjar, the deputy of Aleppo, had departed from the siege of Karkar without his knowledge. The Sham deputy ordered the siege to continue. And found its people in a very strong near the villages of Joseph, and they became calm in the presence of the Sultan. Sultan was very angry at the speed of his departure. He replied with great force and ordered his arrest. He was imprisoned in the Aleppo Citadel, then released from his day and sent to Damascus as an unemployed ${ }^{(7)}$

c) Change Sultan or Prince:

(756AH-1355M) Prince Saif al-Din was one of the princes of Damascus, who had advanced in the days of Qusun and gave him Tablakhanh, when the state was removed from Damascus is unemployed (8)

Stability of the rule of the Sultan and get rid of rivals:

In the year (783 AH-1381M) The Grand Prince was banished to Prince Olabha Ottoman Aldwadar، and also brought out the princes of dozens of exiles. And denied the arrest of forty-three owned by the

(1)Ibn Manzoor: The Sanctuary of the Arabs,(11/56)

(2) Dahman: Dictionary of Historical Phrases in the Mamluk Period, p. 35

(3)Maqrizi: Behavior to know the kings (140/5)

(4) Maqrizi: Behavior to know the kings (416/2)

(5)Son of Tgree Berdy: the stars in the kings of Egypt and Cairo, (210/11)

(6)Ibn Hagar al-Askalani: News of immersion news news (261/1)

(7)Ibn Hagar al-Askalani: News of immersion news news (132/3)/ Maqrizi: Behavior to know the kings $(445 / 16)$

(8)Salah al - Din Safadi: The very important people of the age and agents victory(445/6) 
Levant. And the air of the great prince and saw that he had security, because he took the emirate in the days of Prince Anibk was with him in distress because the same want him what does not qualify him, when the state and became Tchtmr Alli is the prince with you with him a large order is still in Tchtmr till he has been exiled ${ }^{3(9)}$

-In the year(900 AH-1494M) Atabak denied the Egyptian soldiers, Azbek to Mecca heroism, after it occurred in Egypt, a big stroke and the Mamluks of the Sultan ${ }^{(10)}$

d) Violation of orders of the SultanIn.

-In the year(783 AH-1381) AD, the Atabak sent to the throne of Prince Sandown Al-Shaykhouni the second crier and Qardam Al-Hasani, head of the repentance, and directed him and asked him to return to his job and his administration but he did not return , and returned the response to Barqouq so. Then, if he was tempted by this remorse, he regretted his night and sent the sheikh, SheikhAkmal AldineShaykh al-Shaykhuniyya, to ask Birqa to return him to his command and his job. He sent Akmal Aldine to Barqouq but he did not accept that so he decided to go to Jerusalem on foot ${ }^{(11)}$.

e) The dishonor without the right of the Sultan

In the year 853 AH-1449 CE, Sultan exiled Prince Sudoun Al-Sudoun painted the crier, and he accompanied it. He ordered the Sultan to establish a hero in the desert. The reason for the exile of the Sudoun was that he had a misfortune. He was told by Ali ibn al-Iskandar, who is credited with selling half of it and leaving half of it, because there is little grain on the coast. So Sudoun al-Sudoun refrained from doing so. It has been mentioned that this Sudonite Sudon, had hit Aba Alkhair Alnahas in one day twice so he can take Al Abbas money ${ }^{(12)}$

\section{f) Suppressing a particular riot or solving a problem through exile}

In 706 AH1306 CE, when the situation between Bebars and Salar became more complex, they did not meet and prepared the towers' princes. He ordered Bibars and they came riding under their clothes for fear of strife and the people waiting for evil. Every day, the mighty princes rode: the seven battle hugs, the peppers, the dodars, Berlghi and Aybak Khazandar and Sankar Kemali and Baktut Fattah in others to Prince Peppers, and spoke with him in the settlement of evil and suppression of sedition. And they are still in it until the demarcation of the Jawali provided that he went out to the Levant and they went from him to Prince Salar and remained with him to agree on the travel of Jawali, he traveled from his day after cutting his bread and then blessed him after his arrival in Damascus by order Tablakhanh ${ }^{4(13)}$

g) Neglect while performing tasks:

(854AH - 1450 AD) King Al-Muayyed bought Prince Saif al-Din in Sandown Carwash in Salanth and made him king. The Mamluks made him a member of the Sultan until he died in the thirteenth month of Rabee 'Al-Thani in 1954. Jerusalem and the reason for his exile that the Sultan was sent to the lake accompanied by Prince Jerbash Mohammedi, and they went together to the lake and returned and accompanied by Jamal Maharib, which was seized by the detector of the lake, when they arrived at the righteousness of Giza sea descent, and Uday each one of them to Bir Bulaq, and remained in the beauty of a barber, was only an hour and attacked a warrior and took Its beauty, and looted some of the nuclear, and returned to the lake, Vtazm Sultan that, ordered his exile and continued in Jerusalem until he died $865 \mathrm{AH}^{(14)}$

\section{h) Conspiracy}

(787 AH-1385AD) when Prince Abu Bakr bin Sinqar was presented. Hamel al-Hajj, Prince Tamerbaga Al-Hajib was arrested along with a Mamluk wife and severely beaten by the farmers for words that the Sultan had learned from them. And all the owners of the camel on the backs of one of

(9)Maqrizi: Behavior to know the kings(140/5)

(10)Shams al - Din Hanafi: Mafakha Khlen in accidents of time(137/1)

(11)Son of Tgree Berdy: the stars in the kings of Egypt and Cairo(210/11)

(12)The same source(395/15)

(13)Maqrizi: Behavior to know the kings(407/2)

(14)Ibn Tghri Bardi: Al-Manhal Net and fulfilled after the Enough(176/6)

(15)Maqrizi: Behavior to know the kings(183/5) 
them to the back of the other and sing tambourge on camel. And the women and their women are skinny and flattened their cheeks and denied to the Levant ${ }^{(15)}$

In (742 AH-1341 CE), Qatlubgha entered the Sultan and obeyed the obedience of the deputies and their joy in his days. Then the Sultan, Prince Qusun and the other princes became aware of what was being waged against him by Prince Pashtak and that he wanted to oppose him on his way and kill him. Ala Bashtak. When it was the age of this day, the princes entered the service on the custom of the palace, including Prince Bashtak, Prince Qatlubgha al-Fakhri and Prince Teqzadmir the Naziri sailed to Bashtak and took his sword and shoulders. And captured with him his brother Aywan and the length of the Ottomars and owned by the Mamluks of the Sultan were fleeing him. They were all tied. And they went to Alexandria at night ${ }^{5}$

\section{i) Dispute with the Sultan or with a princes}

In the year (676 AH-1277M), after the death of the late King Al-Zaher (may God have mercy on him), Prince Izz al-Din Ayman al-Dhahri, the deputy of the Sultanate, deposed Prince Jamal al-Din alHumeiri. He came to Damascus and arrested him for a long time. He remained in his home on alSalhiyeh Mountain with a hero from the state ${ }^{(17)}$

\section{j) Corruption and infringement of the parish}

In the year (800 AH - 1397 AD) was arrested Sheikh Safawi and arrested because he was an unemployed in Jerusalem, was subjected to women and children forced, complained to him ordered his exile and detention, and Sheikh Safawi of the people of his time and the closest of the Sultan status and then changed it denied ${ }^{(18)}$

In the year (828 AH-1424M), Najmuddin Ibn Haji, the author of the secret, was arrested and then exiled to Damascus. He was accompanied by a policeman with him in a series of iron and very Ahlain. He committed his duty to call upon him in every country he entered. who has something on him, ask it!! And was surrounded by the Department and carry all that, and the reason that he began writing the secret without experience to reform the job and went with the Egyptians his way of creation and difficult initiative with the desire of playing, and he was taking the others money with no right $^{(19)}$

\subsection{The second topic: The places to which it was denied}

\subsubsection{First Places:}

a) Jerusalem:-

$>$ year (852 AH-1448M) King Al-Zaher Baybars took over Idgadi bin Abdullah al-Kabaki on behalf of Safad, then transferred him to the Aleppo Prosecution, Vadam Filb duration, then seized and arrested him, then liberated him, and went to Jerusalem unemployed(206)

$>$ Year (800 AH-1397M) Drainage and isolation of Barada from the state of Aleppo and transferred to Jerusalem unemployed.

$>$ Year (769 AH-167M) Prince Arjun al-Qashtumari was arrested and as an unemployed was taken to Jerusalem. so as Prince Bashtak al-Omari ${ }^{(22)}$.

(16)The same source(332/3)

(17)The tail of the mirror of timeQutb Aldine:

(18)(2/19) Ibn Hagar al-Askalani: The news of immersion news news

(19)Ibn Hagar al-Askalani: The news of immersion news news(2/19)

(20)The same resource(344/3)

(21) Ibn Tajri Baradi: Incidents of the ages in the days and months(45/2)

(22) Maqrizi: Behavior to know the kings(319/4)

(23)The same source(153/6)

(24)The same source $(364 / 6)$

(25)Abo Alfalah Hanbali: The golden things in golden news(316/8) 
Year (808 AH-1405M) Sultan Al-Malik Al-Nasser wrote to Prince Norouz Al-Hafizi in the presence of Jerusalem unemployed and warned of the delay.

$>$ (855 AH-1451) Thursday the eleventh Prince Nasser Al-Din Muhammad Ibn Mubarak Hjoubip the veil of Damascus after the isolation of Anbek Nasserite and headed to Jerusalem unemployed (24).

$>$ (817AH-1414M) Sultan Muayyed Abu Nasr ordered Prince Jerbash Kabbasha to be exiled to Jerusalem and was ordered to take Prince Argun al-Roumi Emir Khor in the days of Nasiriya to Jerusalem. He also asked that he be delayed until after the feast ${ }^{(23)}$.

$>$ Year (758 AH-1356M) from the state of Saleh Saleh Argun al-Saghir al-Kamili was arrested in Alexandria, then released and remained unemployed ${ }^{(25)}$.

\section{Triples}

$>$ Year (745 AH-1344M) Prince Jamal al-Din al-Darmartchi took over the city of Damascus in the days of the Amerilbaga، and the people and the best of them. Then he took over the land of the land. He took him between Medea and al-Baram. He did not disobey him. As it is in the service of people and then he is the guardian of the woman Ahhubip, then isolate from the wedding, and went to Tripoli unemployed.

$>$ (761AH-1359) on the morning of Wednesday, the twenty-fifth of Rajab, the deputy of the Sultanate, Prince Saif al-Din Asnadr, was arrested by the instructions of the Sultan of his exile 'Li Tripoli as an idle ${ }^{(26) 7}$.

\section{b) Damietta}

(801AH-1398) Prince Al-Hajj Bin Mughltai, a deputy in Alexandria, took over the reign of Hajji Bin Al-Ashraf Shaaban, and then he was banished by Barqouq to Damietta ${ }^{(27)}$.

$>$ In the year (780 AH-1378M) Teshtamer was released from the prison of Alexandria and transferred to Damietta where he was a free man ${ }^{(28)}$.

$>$ On the third day of the year (831 AH-1427) on Tuesday, the eighth of Shawwal, the Sultan, Prince Qatj, one of the thousands of Egyptian dhimmers, then Prince Jerbash al-Karimi, prince of the Council, took a Qatj in iron to Alexandria, and he was arrested there, and sent toDamietta as unemployed $^{(29)}$.

\section{c) Hamah}

Year (759 AH-1357M) on Saturday the twenty-first of Dhu al-Hijjah and then denied the courtappointed Taymor Isma'ili to the city of Hama heroin of the saddle ${ }^{(30)}$.

d) Damascus

Year (754 AH-1353 AD) Sultan Sultan Al-Saleh Saleh Al-Amir denied Munjik al-Yusuf ${ }^{(31)}$.

e) Makkah

In the year (831 AH -1427) from the sultan of the Persian Gulf of Persia on Egypt, the king of the proPrince Prince Saif al-Din Yashbq after the killing of Norouz, and then denied to Mecca idle for many years ${ }^{(32)}$.

Year (901 AH-1495M) Atabak denied the Egyptian soldiers, Azbek, to Mecca supervising unemployed $^{(33) 8}$

(26)Salah Safadi: The people of the age and what made them win(9/3)

(27) Ibn Tajri Baradi: Incidents of the ages in the days and months(66/2)

(28)The same source $(175 / 1)$

(29)the same source(319/14)

(30)Ibn Katheer: the beginning and the end(592/18)

(31) Ibn Hagar al-Askalani: The news of immersion news news(343/3)

(32)Ibn Tajri Baradi: Incidents of the ages in the days and months(285/10) 


\section{f) Cairo}

On the fifth of Shaaban, Prince Sultan Sudon al-Sudoun al-Dhahiri denied the court's entrance to Qus, where he accompanied him to Tripoli and then stayed in Cairo ${ }^{(34)}$.

g) Aleppo

Year (880 AH-1475M) The first year was ruled by the king Al-Zaher Barqouq, a decree by Prince Menkali Bgha Ahmadi Al-Baladi to go to Aleppo, unemployed ${ }^{(35)}$.

h) Karak

(778 AH 1376 AD) Sultan Sultan Al-Ashraf honored the Hajj and sent his brothers and cousins to Karak, where they imprisoned and sent with them Sodon Al-Shaykhouni to keep them in custody ${ }^{(36)}$.

The researcher finds that after counting the cities that used to receive the exiles from the dead, it turned out that most of these cities received them, namely Jerusalem, Damietta, Damascus, and Cairo. And I will explain the result:

\begin{tabular}{|l|l|l|l|}
\hline Book news of immersion news & Book of stars shining in the kings of Egypt and Cairo \\
\hline The city & $\begin{array}{l}\text { How many times people has } \\
\text { been denied to }\end{array}$ & The city & $\begin{array}{l}\text { How many times people } \\
\text { has been denied to }\end{array}$ \\
\hline Jerusalem & 32 & Jerusalem & 77 \\
\hline Damascus & 8 & Domiate & 32 \\
\hline Domiate & 6 & Damascus & 18 \\
\hline The Levant & 4 & Cairo & 16 \\
\hline Cairo & 1 & Tripoli & 6 \\
\hline Mecca & 1 & The Levant & 5 \\
\hline Alexandria & 1 & Mecca & 4 \\
\hline Karak & 9 & Aleppo & 2 \\
\hline Aleppo & 3 & Karak, Hamah, Safad & 3 \\
\hline
\end{tabular}

\subsubsection{Second: The Reason that Jerusalem was the Place for the Unemployed}

The researcher finds that in these two books, and other books, Jerusalem was the preferred place for the exiles, but was often accompanied by some of the exiled princes of the Sultan to change the place of exile to Jerusalem, I think this is due to its moderate climate, its location in the middle of the Arab world, its religious status, and the state's interest in this city in all respects. I will mention what I am saying about this through the following:

On the 29th of Shawwal, $827 \mathrm{AH}$, the king of Al-Ashraf Al-Barsbay arrested Al-Mustafari Al-Atabak and carried him to Alexandria. He was imprisoned for a period until the King Al-Ashraf ordered him to stay in Damietta. Remained until the pastor was also transferred to the priest by the intercession of the wife of Khawand Qanqbay ${ }^{(37) 9}$

(779AH-1377M) Sultan Binfi Baidmar ordered from Safad to Tripoli, then he interceded in it and then lived in Jerusalem ${ }^{(38)}$.

The year (821 AH 1418 AD) Nasser Benfi Bisq Amir Ajor virtual to the land of the Roman, when the pro did not accept Bisq to remain in the land of the Romans, and moved to Jerusalem and died in Jumada al-Akhra ${ }^{(39)}$.

(33)the same source(151/15)

(34)Shams Alden: to speak with people about the ages(137/1)

(35) Ibn Tajri Baradi: Incidents of the ages in the days and months(356/15)

(36)the same resource(389/11)

(37) Ibn Tajri Baradi: Incidents of the ages in the days and months(492/3)

(38) Ibn Hagar al-Askalani: The news of immersion news news(153/1)

(39)The same source(179/3)

(40)the same source(215/1) 
(782AH-1308AD) and the guardian of Tishmtr al-Dweidar on behalf of Safad in Rajab, after he left Alexandria to Damietta before that, and continued to Ramadan in the year of four and eighty, he resigned and the request for residency in Jerusalem as an unemployed ${ }^{(40)}$

(767AH-1365M), the land of the princes of the land of the Sultan and Yelbga the Atabek and asked him to release the princes imprisoned in Alexandria, the Sultan accepted their intercession and released the long-time, especially freed and sent to Jerusalem unemployed ${ }^{(41)}$

\subsubsection{Third: The objective of the policy of exile:}

The researcher believes that the main objective is punishment regardless of the causes of the punishment, but the question did not achieve the penalty of imprisonment for the punished person??

Yes, it is realized, but it is noted that the Sultan was aiming at the policy of negation to achieve two things. The first is the absence of this exile from all the details. This is not done with imprisonment, and the second is the alleviation of the exile. The exile is much lighter than the prison, as it was often achieved with the intercession of a close friend. From the Sultan, will be illustrated by examples:

Example 1:

(854 AH-1450M), it was prescribed for the Wali to beat the slave Saadane. The deed and the story of this slave is that when his teacher died, this servant ended up and he was afraid to say, what was Zaini only responded to what he took to go to the home of his teacher and resided in it has been popular in Cairo so that people are calling him to remind him of the people from every vanguard of the visit and to seek his blessing and echoed the people Vuja Vuja and bone so that it does not reach him Whoever has the status or appointed by the people of the state until the Sultan reached his command ordered both to and from Cairo and the judge of the court to strike him with his beating and imprisonment, and when he entered, he feared and he was exiled to Domiate as an unemployed ${ }^{(41) 10}$.

The researcher believes that if we investigated the reason we find this person and not just hit him, we think that the real reason is to put an end to the influence of this slave in the hearts of people at the expense of the Sultan, and this is achieved by negation and not beating, and this makes me wonder why we did not use the policy of exile here In Gaza, instead of the policy of execution, which may have a social impact in some cases, but perhaps the main reason for not applying this policy to us, is that we do not control any of our borders and the lack of formal relations between us and between all other countries, as well as the difference of culture between us and between the Mamluk era on the policy of exile.

\subsection{The third topic / the situation of unemployed social, economic and political}

\subsubsection{First: The social conditions of the unemployed:}

They had a special garment, when the sultan Muzaffar Baybars Gashnikir went to meet the Afram, descended from Farih, the greatest of the Afram Sultan's descent to him and before the ground, and the Afram was full dress and the tension of the middle and (means he attended the body of the unemployed princes ${ }^{(42) 11}$ )

(706 AH-1306M), and he went to Bibris and complained to him. He asked him to be angry and he insulted him, so he insulted the tashlaki in the answer to the answer, and he abhorred the right of the Barwani. Yourself as the Mamluks of the Sultan ${ }^{(43)}$.

They were described as poor, which showed that their social status was low.

And some of them enjoyed a high social status. Prince Gamal al-Din al-Najibi al-Salhi al-Najmi, who died in $677 \mathrm{AH}-1278 \mathrm{M}$, was appointed by his master, the king, and made him the master of his house. To Cairo and set up a large heroine Ballard, high status, and because of illness returned King happy (44).

\subsubsection{Second: The economic conditions of the unemployed}

(41) Ibn Tajri Baradi: Incidents of the ages in the days and months(251/1)

(42)The same source(267/8)

(43) Salah Safadi: The people of the age and what made them win(148/4)

(44)Althahabi: the Islamic history(336/15) 
The economic conditions of the unemployed varied, some of them were granted some of the sectors, and some of them were paid a salary. Some of them were not paid, and some of them were confiscated all their property, that is, their economy is varied and I will show it through examples.

In the year $814 \mathrm{AH}$ (1411 AD), the Sultan appointed twenty-two emirs from the unemployed princes to head to the districts of the provinces of Amir Hazman al-Hasani, Taman al-Nasseri, Sungbaga, Shadi Khaja, and Altenbaga. Two hundred owned, to be the help of the father in Damascus and in his service, and the father was interceded in these mentioned until the Sultan freed them.

\subsubsection{Third: Political situation of the unemployed:}

The return of the unemployed to political life was in the Mamluk state, in accordance with the variables and reasons that led to his exile. In the year (796 AH -1393 AD), the Sultan granted a group of unemployed ministers with jobs under his hand to honor him, and everyone served him $^{(45) 12}$

\subsubsection{Fourth: The military situation of the unemployed}

(784 AH -1382 AD), the unemployed were employed to protect the Sultan. Sultan Al-Zaher AlBarqouq spent the unemployed. He then arranged for the unemployed soldiers to assemble among the balconies of the castle to shoot at the one who might besiege the castle ${ }^{(46)}$.

(803AH-1400M). The mail was received by the Sultan from Aleppo by taking Timur Maltiyeh, and the arrival of the first soldiers of the dates of Linc to the Madinapidian dictator. In the book: Muslims were recognized and only perished. The Sultan summoned the Caliphs, Judges, Princes and State dignitaries two days later. That Timur Lenk arrived at the front of Ghali Marash and Entebbe, and was intended to collect the money and the provision of maintenance in the army, the judges said you are the owners of the matter and theobituary, and you do not have an opposition and said to them we will take half of the Waqf of the country, cut them to the unemployed soldiers, the soldiers said to the many Awqaf ${ }^{(47) 13}$.

$(827 \mathrm{AH}-1423 \mathrm{H})$, the preacher of the Hajj, told the security and prosperity and the abundance of rain, but Sharif Hassan bin Ajlan did not meet the Prince of Hajj and left Mecca for what is known that the Sultan wants to arrest him, the Sultan was angry that the unemployed Mamluks were called to make a joke To fight the supervision of Mecca.

\subsection{The fourth topic: The target of the policy of exile and the duration of exile:}

\subsubsection{First: Targeted by policy}

a) Civil Jobs

$>$ Ministers (year 852 AH-1448M) Minister Al-Saheb Karim Al-Din Abdul Karim, known as the son of the writer of climates, died after he was exiled to Cairo and found unemployed

$>$ The Princes (854 AH-1450M) Arqmas bin Abdullah Al-Dhahiri Al-Dardar, Prince Saif al-Din Benfee Prince Azbek Al-Dawadar Jerusalem

$>$ Governorates (year 786 AH-1384M) Tishmtr bin Abdullah Al-Ala al-Dawadra. He was the great dowadarian in the Egyptian Diyala. He was then deported to Damietta, where he lived for a period of time. He was then transferred to Jerusalem, where he lived until he died $786^{(48)}$

$>$ The accountants: year (862 AH-1457 m) Matt Yar Ali bin Nasrallah Al-Ajmi Al-Khorasan AlTaweel, calculated by Cairo,

$>$ The criers (754 AH-1353 AD) Prince Pegra Al-Mansouri died one of the princes of Al-Aluf in Diyar of Egypt. He was a hero in Aleppo and was better than he took over Juba ${ }^{(49)}$.

(45) Ibn Tajri Baradi: Incidents of the ages in the days and months(121/13)

(46) Ibn Tajri Baradi: Incidents of the ages in the days and months(152/12)

(47) Ibn Tajri Baradi: Incidents of the ages in the days and months(278/11)

(48) Ibn Tajri Baradi: Incidents of the ages in the days and months(218/12)

(49) Ibn Tajri Baradi: Incidents of the ages in the days and months(260/14) 
The signatories (year 727 AH-1326M) appointed Muhammad bin Mansour Shams al-Din, the site of Gaza, where he lived for a long time began to sign and write the army and then Prince Saif alDin secures his isolation from Gazaand became an unemployed.

\section{b) Military functions}

$>$ Head of the Army: (754 AH-1353 CE) President Amin al-Daban Ibrahim bin Yusuf, known as the writer of Teshtamer, the army's commander in the Visible Dynasties took a period of time, then he was removed and removed to the pastor, where he lived for a period of time and then returned to Cairo until he died(50)14.

$>$ Prince of arms: (year 872 AH-1467M) Prince Karkmash Amir Abdul traveled to Damietta unemployed by his desire

$>$ Independent posts:

$>$ Judges: (745 AH-1344M) the great judge was denied, McCain Al Den and lived in Egypt unemployed(51).

The scholars: In the year $703 \mathrm{AH}-1303 \mathrm{AD}$, a group of Fuqua 'was established in the days of Qarasnqr, and a lot of harm came to him from Qarasnqr, and he feared for himself. Then he went to the judge of Taqi al-Din al-Hanbali and asked him to rule his Islam and inject his blood. And he was sentenced to do so. Then the decree was issued from Egypt by isolating him from all his sides and he remained unemployed ${ }^{(52)}$.

\subsubsection{Second: Duration of exile}

There was no specific time limit for exile according to sources. The duration of exile ranged from one month to the next, and I will indicate through the sources on this subject ${ }^{(53)}$

Year (764 AH-1362) Isolation of Hassan bin Omar Al-Sahab Badr al-Din and stayed in his home unemployed in Damascus for a period not exceeding two months, and then asked him to go to Egypt

When Prince Saif al-Din Sarghatmesh seized Zia al-Din al-Dimashqi and sent him to Qus, he went to her, and set up a year and more. Then he was drawn back to Cairo, and he lived in his house until he $\operatorname{died}^{(54)}$

$>$ In the year $741 \mathrm{AH}-1340 \mathrm{M}$, Muhammad ibn Tammam was deposed by the judge of the judiciary, and it lasted for more than three years and then was reinstated(55)15

$>$ Year (728 AH-1327M) Tnkz Vice-Sham removed the Shams al-Din al-Khudari to Safed and lived there unemployed 4 years.

The researcher finds that the period of exile was determined by the decision-maker, not related to the size of the offense or guilt committed by the exiled person, and often find that the exiled person has a desire to stay longer in exile, on more than one side like the city of Jerusalem.

\section{RESEARCH RESUltS}

Through this research, the researcher reached many important results related to the policy of exile and exclusion in the Mamluk state:

- There is a relationship between the term unemployed and the term exile. Every unemployed man is not all unemployed. The meaning of the unemployed is that he has no job and can be unemployed in his own country, but every exile is unemployed because he will be separated from his job once the decision of exile.

(50) Maqrizi: Behavior to know the kings(188/4)

(51) Salah Safadi: The people of the age and what made them win(52/5)

(52) Ibn Tajri Baradi: Incidents of the ages in the days and months(294/10)

(53) Ibn Tajri Baradi: Incidents of the ages in the days and months(386/16)

(54) Salah Safadi: The people of the age and what made them win(112/1)

(55) Maqrizi: Behavior to know the kings(12/5) 
- Every case of exile has its own reasons, such as opposition to the leadership's decisions by illegal means, political competition, rebellion against the state, failure to carry out the tasks entrusted to the person.

- The one who is subject to the decision of exile and deportation, offering mediation to the Sultan from exile to the city of Jerusalem in Palestine.

- The Mamluks suffered a lot of internal disturbances, from rebellions, pockets and revolutions that were one of the means to eliminate the few and to protect the home front to follow the policy of exile and deportation.

- The unemployed or the exiles were assemblies, they had their own clothing, and their economic and social conditions varied

- The exile was much less humiliating than the decision of the prison. It was he who interceded in the jailed princes to be exiled or removed from state jobs.

- The policy of exile and exclusion extended to most of the factions in the Mamluk state, beginning with the deputy of the Sultan and ending with the exile of the slaves

- The work of the unemployed, whether they were exiles or residents, focused on military actions, earning their livelihood, and other works.

- The exiles had an important role in a number of areas in the cities that spent their exile, especially in the educational and urban areas.

\section{REFERENCES}

[1] Abu al-Fidaa Isma'il ibn 'Umar ibn Qatheer al-Qurashi al-Basri and then al-Dimashqi (died $774 \mathrm{AH}$ ).

[2] The beginning and end, the realization of Abdullah bin Abdul Mohsen al-Turku, Publisher: Dar Hager Publishing, Publishing, Distribution and Advertising, edition: First, 1418 AH-1997, Publishing Year 1424 AH / 2003 AD, Number of parts: 21 (20 volumes and indexes).

[3] Abu al-Fadl Ahmad bin Ali bin Mohammed bin Ahmed bin Hagar al-Askalani (died: 852 e) News of immersion news, investigator: d. Hassan Habashi, Publisher: Supreme Council for Islamic Affairs, Committee on the Revival of Islamic Heritage, Egypt, Publishing Year: 1389 AH, 1969, Number of Parts 4.

[4] Abu Bakr ibn Ahmad ibn Muhammad ibn 'Umar al-Asadi al-Shibhi al-Damashqi, Taqi al-Din Ibn alZubayh (851 AH) Layla Al-Shafa'i, Investigator: Dr. Al-Hafiz Abd Al-Aleem Khan, Publishing House: Alam Al-Kitab - Beirut, edition: First, 1407 AH, number of parts 4.

[5] Ahmad bin Ali bin Abdul Qadir, Abu al-Abbas al-Husseini al-Ubaidi, Taqi al-Din al-Maqrizi (died: 845e ) Behavior to Know the States of Kings, Investigator: Muhammad Abd al-Qader Atta, Publisher: Dar alKuttab al-Ulmiyya - Lebanon / Beirut, edition: 1, 1418-1997, number of parts 8

[6] Shams al-Din Abu Abdullah Mohammed bin Ahmed bin Othman bin Qaimaz Golden (died 748 e) History of Islam and the Deaths of Celebrities and Media, Investigator: Dr. Bashar Awwad Ma'arouf, Publisher: Dar al-Gharb al-Islami, First edition 2003, number of parts 15.

[7] Shams al-Daim Muhammad ibn Ali ibn Khamarwiya ibn Tulun al-Damshqi Salhi Hanafi (died 953 e) Mafakha al-Khulan in the events of time and the development of his senses: Khalil Mansour, Publisher: Dar al-Kuttab Al-Ulmia, Beirut Lebanon, edition: first 1418 e-1998, number of parts 1

[8] Salah al-Din Khalil bin Aibek Safadi (died 764 e) A'ayan of the age and the agents of victory, Muhajqd. Dr. Mahmood Salem Mohammed, Presented by: Mazen Abdel-Qader Al-Mubarak, Publisher: Contemporary Thought House, Beirut, Lebanon, Dar Al-Fikr, Damascus, Syria, First Edition, and Number of parts5

[9] Abd al-Hayy ibn Ahmad ibn Muhammad ibn al-'Ammad al-'Aqri al-Hanbali, Abu al-Falah (died 1089) AlMuhammad al-Zahab in the news of gold, the investigator: Mahmoud Al-Arnaout, came out of his conversations: Abdul Qadir Arnaout, Publisher: Dar Ibn Katheer, Damascus - Beirut, edition: First, 1406 H-1986, number of parts 11

[10] Qutb al-Din Abu al-Fath Musa bin Muhammad al-Yunini (died 726 e) The Mirror of Time, Carefully: The Ministry of Political Investigations and Cultural Affairs of the Indian Government, Publisher: Dar al-Kitab al-Islami, Cairo, Second Edition, 1413H-1992M, Number of Parts 4.

[11] Mohammed Ahmed Dahman (died 1409 AD) Glossary of Historical Terminology in the Mamluk Period, Publisher: Dar al-Fikr al-Mu'awar, Beirut, Lebanon, Dar al-Fikr, Damascus, Syria, first edition 1410H1990AD. 
[12] Muhammad ibn Makram bin Ali, Abu al-Fadl, Jamal al-Din Ibn Manzoor al-Ansari al-Ruwaifi (died 711 AH) Sansan Al Arab, Publisher: Dar Sader, Beirut, 3rd ed., 1414H, number of parts 15.

[13] Yousef bin Tgri Bardi bin Abdullah Al-Dhahiri Al-Hanafi, Abu Al-Mahasen, Gamal Al-Din (died 874 $\mathrm{AH})$ The Glorious Stars in the Kings of Egypt - Cairo, Publisher: Ministry of Culture and National Guidance, Dar Al Ketub, Egypt, Number of parts16.

[14] Yousef bin Tgri Bardi bin Abdul Dhaheri Hanafi, Abu al-Mahasen, Jamal al-Din (died 874 e) Da'amat alDahr in the days and months, Investigation: Dr. Muhammad Kamal al-Din Izz al-Din, Publisher: Alam alKitab, First edition: 1410H-1990M, number of parts: 2.

[15] Yousef bin Tgri Bardi bin Abdul Dhaheri Hanafi, Abu al-Mahasen, Jamal al-Din (died 874 e) Al-Manhal Al-Safi and Al-Mustafa Al-Wafi, achieved and developed by Dr. Mohamed Mohamed Amin, Said Abdel Fattah Ashour, Publisher: The Egyptian General Book Organization, Number of parts: 7.

[16] Shafiq Jasser Ahmed Mahmoud The Mamluks and Their Saints on the Crusaders in the Levant, Publisher: Islamic University of Medina, ed., 1st, No. of Parts: 1

Citation: Ghassan Weshah. "The Policy of Exile and Exclusion in the Mamluk State”. International Journal of History and Cultural Studies (IJHCS). vol 4, no. 1, 2018, pp. 110-120 doi: http://dx.doi.org/ 10.20431/2454-7654.0401008.

Copyright: (C) 2018 Authors. This is an open-access article distributed under the terms of the Creative Commons Attribution License, which permits unrestricted use, distribution, and reproduction in any medium, provided the original author and source are credited. 